\title{
ASPEK HUKUM TANGGUNG JAWAB NEGARA TERHADAP \\ PERLINDUNGAN ANAK TERLANTAR DITINJAU DARI PASAL 34 \\ AYAT 1 UNDANG-UNDANG DASAR NEGARA REPUBLIK INDONESIA \\ TAHUN 1945
}

\author{
Anna Syahra \\ (Mahasiswi Program S1 Fakultas Hukum Universitas Tarumanagara) \\ (Email:Nasyahra@yahoo.com)
}

Mulati

(Corresponding Author)

(Dosen Hukum Perlindungan Anak Fakultas Hukum Universitas Tarumanagara, Meraih Sarjana Hukum dari Fakultas Hukum Universitas Tarumanagara, Magister Hukum dari Fakultas Hukum

Universitas Tarumanagara)

\begin{abstract}
Children is a gift from god that we need to keep, protect and take care of, as good as we can. It was the philosophy which created the idea of the Nation has responsibilities to take care of the waifs. Constitution of Indonesia has been adopted the idea then mandating our nation to take care the destitude and the waifs. The idea itself has been created in the form of regulation in Indonesia, therefore, Indonesia that represented by the government liable to protect and take care of the waifs. In the other hand, the waifs in Indonesia still shown the big number of quantity, it means, there is a problem in the system of handling the waifs that used by the government to fulfill the rights of the waifs. As a regulation mandates the government to fulfill the rights of the waifs and also protect and take care of the waifs, the government faced the obstacle. The obstacle has raised from many factor, such as regulation, the integration between institution related to the waifs, the funds, and the involvement of the public are not used by the government. The obstacle itself cause the government can not perform the obligation to fulfill and protect the rights of the waifs effectively and perfectly.
\end{abstract}

Keywords: The Waifs, Protection of Children, Childern's Rights 


\section{Pendahuluan}

\section{A. Latar Belakang}

Anak merupakan rezeki, titipan, dan karunia dari Tuhan Yang Maha Esa yang harus dikasihi dan cintai. Keberadaan mereka adalah sebagai anugerah yang harus dijaga, dilindungi, di rawat serta terjamin hak-haknya. Anak juga merupakan bagian dari Sumber Daya Manusia (SDM) yang harus di didik dan terdidik dengan baik dan optimal di dalam lingkup tumbuh berkembangnya hingga menjadi manusia dewasa yang dapat memiliki potensi dan eksistensi untuk pembangunan nasional dan kejayaan negeri. Dengan kata lain, keberhasilan dan kegagalan seorang anak dalam melewati masa tumbuh kembang menjadi suatu yang sangat berpengaruh karena anak memiliki peran strategis dalam pembangunan bangsa dan negara. Oleh karena itu anak wajib dilindungi dan tidak seharusnya seorang anak kehilangan hak-haknya yang mana terjadi pada anakanak terlantar.

Merujuk dari Kamus Umum Bahasa Indonesia mengenai pengertian anak secara etimologis diartikan dengan manusia yang masih kecil ataupun manusia yang belum dewasa. ${ }^{1)}$ Menurut R.A. Kosnan "Anak-anak yaitu manusia muda dalam umur muda dalam jiwa dan perjalanan hidupnya karena mudah terpengaruh untuk keadaan sekitarnya". ${ }^{2)}$ Kemudian, Romli Atmasasmita, menyatakan bahwa anak adalah seseorang yang masih dibawah usia tertentu dan belum dewasa serta belum kawin. ${ }^{3)}$ Dalam Hukum Positif Indonesia juga memberikan Pengertian anak, seperti dalam Undang-Undang tentang Perlindungan Anak Nomor 35 tahun 2014 tentang perubahan atas Undang-Undang Nomor 23 tahun 2002 (Selanjutnya disebut UU Perlindungan Anak), berdasarkan Pasal 1 Ayat (1) UU Perlindungan

1) W.J.S. Poerwadarminta, Kamus Umum Bahasa Indonesia, (Jakarta: Balai Pustaka, 1984), 25

${ }^{2)}$ R.A. Koesnan, Susunan Pidana dalam Negara Sosialis Indonesia, (Bandung :Sumur, 2005), 113.

${ }^{3)}$ Romli Atmasasmita, Problema Kenakalan Anak-Anak/ Remaja (Yuridis Sosio Kriminologis), (Bandung: Armico,1983), 25. 
Anak, Anak adalah seseorang yang belum berusia 18 (delapan belas) tahun, termasuk anak yang masih dalam kandungan. ${ }^{4}$

Dalam Undang-undang Nomor 4 Tahun 1979 tentang Kesejahteraan Anak (Selanjutnya disebut UU Kesejahteraan Anak) juga menjelaskan bahwa, Yang disebut anak adalah seseorang yang belum mencapai umur 21 (dua puluh satu) tahun dan belum pernah kawin (Pasal 1 Ayat (2)). Selanjutnya, Perlindungan adalah pemberian jaminan atas kemanan, kesejahteraan dan kedamaian dari perlindungan atas segala bahaya yang mengancam pihak yang dilindungi dan Perlindungan Hukum adalah hal perbuatan melindungi menurut hukum. ${ }^{5}$ ) Sehingga, dapat dikatakan bahwa Perlindungan anak merupakan pemberian jaminan atas keamanan, kesejahteraan dan kedamaian atas kehidupan seseorang yang masih dibawah 18 (delapan belas) tahun.

Undang-Undang Dasar Negara Republik Indonesia 1945 (yang selanjutnya disebut sebagai UUD NRI 1945) telah memberikan suatu perlindungan terhadap anak yang dituangkan dalam Pasal 28B Ayat (2) yang berbunyi "Setiap anak berhak atas kelangsungan hidup, tumbuh, dan berkembang serta berhak atas perlindungan dari kekesaran dan diskriminasi" dan kemudian diimplementasikan dalam UU Perlindungan Anak yang menjelaskan dalam Pasal 1 Ayat (2) bahwa "Perlindungan Anak adalah segala kegiatan untuk menjamin dan melindungi Anak dan hak-haknya agar dapat hidup, tumbuh, berkembang, dan berpartisipasi secara optimal sesuai dengan harkat dan martabat kemanusiaan, serta mendapat perlindungan dari kekerasan serta diskriminasi”. Sehingga dapat dikatakan bahwa hukum positif Indonesia telah mengatur mengenai perlindungan anak yang mencakup pula pemenuhan atas hak-hak yang harus didapatkan oleh seorang anak tanpa adanya diskriminasi.

Lebih lanjut lagi, Negara Indonesia juga mewujudkan perlindungan hukum terhadap berbagai kebebasan dan hak asasi anak (fundamental rights and freedom

\footnotetext{
${ }^{4)}$ Indonesia, Undang-Undang Nomor 35 Tahun 2014 tentang Perubahan atas UndangUndang Nomor 23 Tahun 2003 tentang Perlindungan Anak, Pasal 1 Ayat (1).

${ }^{5)}$ Nurini Aprilianda. Perlindungan Hukum terhadap Tersangka Anak dalam Proses Penyidikan. Tesis Program Studi Ilmu Hukum, Program Pasca Sarjana Universitas Brawijaya: Malang, 2001), hal. 41 dalam Abintoro Prakoso, Hukum Perlindungan Anak, Cetakan Pertama, (Yogyakarta: LaksBang PRESSindo,2016), 4.
} 
of children) dan berbagai kepentingan yang berhubungan dengan kesejahteraan anak yang dituangkan dalam Undang-Undang Nomor 4 Tahun 1979 tentang Kesejahteraan Anak (yang selanjutnya disebut sebagai UU Kesejahteraan Anak), UU Kesejahteraan Anak menyatakan bahwa setiap anak berhak atas pemeliharaan dan perlindungan sejak dalam kandungan sampai dengan sesudah dilahirkan. Di dalam Undang-Undang Kesejahteraan Anak Pasal 4 Ayat (1) menyebutkan "Anak yang tidak mempunyai orang tua berhak memperoleh asuhan oleh negara atau orang atau badan."

Serta dalam Pasal 5 Ayat (1) yang berbunyi "Anak yang tidak mampu berhak memperoleh bantuan agar dalam lingkungan keluarganya dapat tumbuh dan berkembang dengan wajar". Dari kedua Pasal tersebut dapat diartikan bahwa Negara memiliki peran dalam memberikan asuhan, pelayanan, dan perlindungan terhadap anak yang tidak memiliki orang tua dan tidak mampu guna mewujudkan hak-hak yang semestinya diperoleh agar anak dapat tumbuh dalam lingkup perkembangan yang wajar dan memperoleh kesejahterannya sebagai anak.

Dalam hal perlindungan anak seperti apa yang telah dijelaskan sebelumnya, pemerintah pun memang telah diamanatkan untuk mengurus anak-anak terlantar, yaitu anak yang tidak terpenuhi kebutuhannya secara wajar, baik fisik, mental, spritiual, maupun sosial. ${ }^{6}$ Hal ini dituangkan dalam Pasal 34 Ayat 1 UUD NRI 1945 yang berbunyi "Fakir miskin dan anak-anak yang terlantar dipelihara oleh negara.". Ayat tersebut secara garis besar memberikan dasar pemikiran bahwa negara wajib untuk memelihara dan memberikan perlindungan terhadap anak yang hak-haknya tidak terpenuhi (terlantar) untuk mendapatkan perlindungan serta pemenuhan atas hak-haknya sebagai anak.

Lebih lanjut lagi, Peran pemerintah dalam mewujudkan perlindungan terhadap anak juga diatur dalam UU Perlindungan Anak Pasal 21 Ayat (1) yang berbunyi "Negara, Pemerintah dan Pemerintah Daerah berkewajiban dan bertanggung jawab menghormati pemenuhan Hak Anak tanpa membedakan suku, agama, ras, golongan, jenis kelamin, etnik, budaya dan bahasa, status hukum,

\footnotetext{
${ }^{6}$ Indonesia, Undang-Undang Nomor 35 Tahun 2014 tentang perubahan atas UndangUndang Nomor 23 Tahun 2003 tentang Perlindungan Anak, Pasal 1 Ayat (6).
} 
urutan kelahiran dan kondisi fisik dan/atau mental.”, Pasal 21 Ayat (2) yang berbunyi "Untuk menjamin pemenuhan Hak Anak sebagaimana dimaksud pada Ayat (1), negara berkewajiban untuk memenuhi, melindungi, dan menghormati Hak Anak.", Pasal 23 Ayat (1) yang menyatakan bahwa "Negara, Pemerintah dan Pemerintah Daerah menjamin perlindungan, pemeliharaan dan kesejahteraan Anak dengan memperhatikan hak dan kewajiban Orang Tua, Wali, atau orang lain yang secara hukum bertanggung jawab terhadap Anak.”, dan Pasal 23 Ayat (2) yang berbunyi "Negara, Pemerintah dan Pemerintah Daerah mengawasi penyelenggaraan Perlindungan Anak."

Namun dalam praktiknya, Peran Pemerintah seperti yang tertulis dalam Pasal 34 Ayat 1 UUD NRI 1945 bahwa fakir miskin dan anak terlantar dipelihara oleh negara dan adanya UU Perlindungan Anak nampaknya tidaklah terealisasikan dengan baik. Dalam realitanya, tidak sedikit dijumpai fakta bahwa anak tak selalu mendapatkan haknya secara penuh, banyak dari mereka yang tidak dapat pendidikan dan perlindungan yang layak. Jelas anak dan pendidikan adalah dua hal yang berkaitan sangat erat.

Tak sedikit dari mereka mengemis dijalanan, dikolong jembatan atau plosokplosok ibu kota untuk mengamen demi mencari uang guna mempertahankan hidupnya di usia yang sangat belia yang tidak seharusnya seorang anak diperkerjakan atau bekerja seperti itu, menghabiskan waktu mereka mengorbankan waktu bermain, belajar, sekolah dan pastinya menguras tenaga hanya untuk sesuap nasi di kehidupan jalanan yang kejam dan mengancam nyawa. Tak sedikit dari mereka disiksa oleh preman baik secara fisik maupun mental.

Data dari KPAI (Komisi Perlindungan Anak Indonesia) dalam websitenya menyebutkan bahwa terdapat 6.192 anak di seluruh Indonesia yang memiliki permasalahan sosial dan dalam situasi darurat (Anak Terlantar, Anak dalam Keadaan Darurat, Anak Korban Bencana) dan terdapat 3.440 anak di seluruh Indonesia yang merupakan korban penelantaran Ekonomi (Hak Nafkah). ${ }^{7)}$

\footnotetext{
${ }^{7)}$ Bank Data Komisi Perlindungan Anak Indonesia. Data Kasus Perlindungan Anak Berdasarkan Lokasi Pengaduan dan Pemantauan Media Se-Indonesia Tahun 2011-2016. http://bankdata.kpai.go.id/tabulasi-data/data-kasus-se-indonesia/data-kasus-perlindungan-anak-
} 


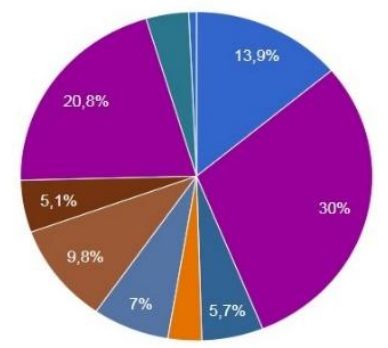

- Sosial dan Anak Dalam Situasi Darura

- Keluarga dan Pengasuhan Alternatí

Agama dan Budaya

Hak Sipil dan Partisipasi

Kesehatan dan Napza

- Pendidikan

- Pornografi dan Cyber Crime

- Anak Berhadapan Hukum (ABH)

Trafficking dan Eksploitasi

- Lain-Lain

Diagram Data Kasus Perlindungan Anak Berdasarkan Lokasi Pengaduan dan Pemantauan Media Se-Indonesia Tahun 2011-2016. ${ }^{8)}$

Dari data yang telah dipaparkan di atas memperlihatkan suatu angka yang terbilang cukup besar dan merupakan kondisi darurat terhadap keberadaan anak terlantar di Indonesia. Lebih lanjut lagi, berdasarkan data dari Pusat Data dan Informasi Kesejahteraan Sosial Kementerian Sosial RI menyatakan jumlah anak jalanan pada 2015 sebanyak 33.400 anak tersebar di 16 Provinsi. Jika dikaitkan dengan tanggung jawab negara dalam Pasal 2 ayat (1) UU Kesejahteraan Anak yang berbunyi "Anak yang tidak mempunyai orang tua berhak memperoleh asuhan oleh negara atau orang atau badan." maka peran negara disini harus memberikan kesejahteraan kepada anak agar tidak ada lagi peningkatan angka pada anak-anak terlantar. Terdapat salah satu program pemerintah yang menyatakan bahwa Indonesia Bebas Anak Jalanan 2017 yang mana merupakan program lanjutan tahun 2011-2014 yang diselenggarakan oleh Kementerian Sosial. $^{9)}$

Faktanya pada tahun 2017 dikabarkan Angka Putus Sekolah di Indonesia juga merupakan salah satu pemicu menigkatnya anak terlantar di Indonesia. Berdasarkan Pasal 9 Ayat (1) UU Perlindungan Anak dikatakan bahwa "Setiap anak berhak memperoleh pendidikan dan pengajaran dalam rangka pengembangan pribadinya dan tingkat kecerdasannya sesuai minat dan bakatnya.”. Pasal ini merupakan bentuk penjelasan dari tujuan negara yang

berdasarkan-lokasi-pengaduan-dan-pemantauan-media-se-indonesia-tahun-2011-2016\#sumbar. Diakses Pada 10/12/2017 10.22.

${ }^{8)}$ Bank Data Komisi Perlindungan Anak Indonesia. Loc.Cit.

${ }^{9)}$ Anonim, http://poskotanews.com/2016/11/27/mensos-deklarasikan-indonesia-bebasanak-jalanan-2017/. Diakses Pada 12/2/1018 22.40. 
terkandung dalam UUD NRI 1945 alenia ke IV yang berbunyi "Mencerdaskan kehidupan bangsa".

\section{B. Perumusah Masalah}

Berdasarkan latar belakang yang telah diuraikan sebelumnya, maka untuk lebih memfokuskan penelitian ini dirumuskan permasalahan sebagai berikut:

1. Apakah tugas dan kewajiban negara dalam pemenuhan hak anak terlantar?

2. Apakah tugas dan kewajiban yang dilakukan oleh negara sudah sesuai dengan Pasal 34 Ayat 1 Undang-Undang Dasar Negara Repubik Indonesia Tahun 1945?

\section{Pembahasan}

\section{A. Tugas dan Kewajiban Negara dalam Pemenuhan Hak Anak Terlantar}

Undang-undang Dasar Negara Republik Indonesia 1945 (UUD NRI 1945) adalah Landasan konstitusional Negara Kesatuan Republik Indonesia. UUD NRI 1945 adalah sebagai hukum dasar tertinggi dalam penyelenggaraan kehidupan berbangsa dan bernegara yang telah di amandemen empat kali pada tahun 1999, 2000, 2001, 2002 dan menghasilkan rumusan Undang - Undang Dasar yang jauh lebih kokoh untuk menjamin hak konstitusional warga negaranya. Seperti yang telah diamanatkan di dalam Pasal 34 Ayat 1 yang berbunyi "fakir miskin dan anak terlantar dipelihara oleh Negara." Dimana Negara melalui Pemerintah memiliki peran penting untuk memelihara, mengasuh, mengurus, serta merawat anak terlantar dan fakir miskin yang ada di Indonesia. Melihat dari arti kata "Pelihara" yang memiliki arti rawat dan jaga menurut Kamus Besar Bahasa Indoneisa, Negara telah diamanatkan tanggung jawab oleh konstitusi untuk menjaga serta merawat anak terlantar dan fakir miskin di Indonesia. Hal ini dilakukan guna memenuhi hak-hak hidup anak terlantar dan fakir miskin.

Adapun pengertian anak terlantar seperti yang di jelaskan dalam Pasal 1 ayat 6 Undang-Undang Nomor 35 Tahun 2014 tentang Perlindungan Anak bahwa "Anak Terlantar adalah Anak yang tidak terpenuhi kebutuhannya secara wajar, 
baik fisik, mental, spiritual, maupun sosial" dan pasal 1 Ayat 7 Undang-Undang No 4 Tahun 1979 tentang Kesejahteraan Anak juga menjelaskan “Anak terlantar adalah anak yang karena suatu sebab orang tuanya melalaikan kewajibannya sehingga kebutuhan anak tidak dapat terpenuhi dengan wajar baik secara rohani, jasmani maupun sosial." Di dukung dengan Pasal 20 UU Perlindungan Anak yang menyebutkan bahwa "Negara, Pemerintah, Pemerintah Daerah, Masyarakat, Keluarga, dan Orang Tua atau Wali berkewajiban dan bertanggung jawab terhadap penyelenggaraan Perlindungan Anak."

Lebih lanjut lagi dalam Pasal 22 Undang-Undang Perlindungan Anak Nomor 35 Tahun 2014 atas perubahan Undang-Undang Nomor 23 tahun 2002 menjelaskan bahwa "Negara, Pemerintah dan Pemerintah Daerah berkewajiban dan bertanggung jawab memberikan dukungan sarana, prasarana, dan ketersediaan sumber daya manusia dalam penyelenggaraan perlindungan anak." Memiliki arti bahwa Negara, Pemerintah, Pemerintah Daerah selain bertanggung jawab atas perlindungan anak terlantar juga berkewajiban memberikan perlindungan berupa dukungan sarana dan prasarana dalam menyelenggarakan perlindungan terhadap pemenuhan hak-hak anak terlantar. Adapun arti Perlindungan Anak sendiri telah dituangkan dalam Pasal 1 Ayat 2 UndangUndang Perlindungan Anak, memiliki arti bahwa: "Perlindungan anak adalah segala kegiatan untuk menjamin dan melindungi anak dan hak-haknya agar dapat hidup, tumbuh, berkembang, dan berpartisipasi secara optimal sesuai dengan harkat dan martabat kemanusiaan, serta mendapat perlindungan dari kekerasan dan diskriminasi”. Perlidungan Anak yang akan diberikan kepada anak-anak terlantar memiliki tujuan yang mana telah di atur di dalam Pasal 3 UndangUndang Perlindungan Anak, mengatakan bahwa perlindungan anak bertujuan untuk menjamin terpenuhinya hak-hak anak agar dapat hidup, tumbuh, berkembang, dan berpartisipasi secara optimal sesuai dengan harkat dan martabat kemanusiaan, serta mendapatkan perlindungan dari kekerasan dan diskriminasi, demi terwujudnya anak Indonesia yang berkualitas, berakhlak mulia, dan sejahtera. Selain itu, terdapat Asas Hak untuk hidup, kelangsungan hidup, dan perkembangan (The rights to life, survival and development) yaitu Asas yang 
mendasarkan pada hak untuk hidup, kelangsungan hidup, dan perkembngan adalah asas yang menekankan bahw setiap anak mempunyai hak untuk hidup dengan aman, tentram, damai, bahagia, sejahtera lahir dan batin, serta berhak atas pemenuhan kebutuhan dasarnya untuk tumbuh dan berkembang secara layak, dan hak untuk mencapai standar hidup yang layak bagi perkembangan fisik, mental, spiritual, moral, dan sosial anak yang harus dipenuhi oleh pihak-pihak yang disebutkan oleh UU Perlindungan Anak memiliki kewajiban dan tanggungjawab untuk itu, yaitu orangtua, masyarakat, dan pemerintah.

Menurut penulis, di Indonesia sendiri, sudah terdapat payung hukum yang jelas mengenai hak-hak anak yang harus di penuhi. Hak-hak anak yang harus di terpenuhi tersebut tertuang di dalam Undang-Undang Kesejahteraan anak dan Undang-Undang Perlindungan anak. Adapun hak-hak anak yang terdapat di dalam Undang-undang Kesejahteraan Anak, yaitu dalam Pasal 2 sampai dengan Pasal 8. Selanjutnya, hak hak anak yang disebutkan dalam Undang-undang Perlindungan Anak yaitu terdapat dalam pasal 4 sampai dengan Pasal 18.

1. Undang-Undang Nomor 4 Tahun 1979 tentang Kesejahteraan Anak;

Undang-Undang Kesejahteraan Anak dalam Pasal 2 Ayat 1,2,3, dan 4 menjelaskan mengenai hak dasar bagi anak yaitu, seorang anak dalam masa pertumbuhannya berhak mendapatkan perawatan dalam bentuk pengasuhan yang di selimuti dengan cinta dan kasih yang baik diberikan saat berada di dalam keluarga maupun diluarkan keluarga serta di dukung dengan pelayanan-pelayanan yang dapat membantu meningkatkan daya kemampuannya yang dapat membentuk karakter anak menjadi karakter yang sesuai dengan kepribadian bangsa agar kelak tumbuh menjadi warga negara yang berguna baik bagi nusa dan bangsa. Selain diberikan dukungan dalam bentuk pelayanan yang diberikan kepada anak, anak juga berhak atas perlindungan baik perlindungan secara khusus yang diberikan di dalam keluarga maupun di luar lingkup keluarga agar terhindar dari hal-hal yang dapat membahayakan masa pertumbuhannya. Dalam pasal 3 UU Kesejahteraan anak juga dijelaskan bahwa dalam setiap keadaan dan dalam keadaan yang dapat mengancam bahaya, seorang anak wajib mendapatkan pertolongan. Sehingga dapat disimpulkan seorang anak berhak mendapatkan perlindungan khusus, 
Karena pada dasarnya seorang anak sejak dalam kandungan maupun telah lahir berhak atas perlindungan yang merupakan hak dasar bagi anak.

Pasal 4 Ayat 1 dan 5 Ayat 1 UU Kesejahteraan Anak telah mengatur bahwa dalam memberikan perlindungan bagi anak, anak yang tidak memiliki orang tua, tidak mampu atau memerlukan pertolongan khusus wajib di pelihara oleh Negara, Pemerintah, Pemerintah Daerah atau Badan dalam bentuk diberikan perawatan dan pengasuhan serta pertolongan yang dapat membantu anak untuk tumbuh dan berkembangan secara wajar seperti anak pada umumnya. Selanjutnya, dalam Pasal 6 Ayat 1 ,7, dan 8 menjelaskan mengenai seorang anak yang berada dalam golongan khusus (cacat atau distabilitas) wajib diberikan dan mendapatkan pelayanan serta asuhan khusus yang dapat membantu anak-anak tersebut untuk tumbuh dan berkembang secara optimal dengan keterbatasan dan kemampuan yang mereka miliki dan membantu meminimalisir hal-hal yang dapat menghambat perkembangan anak-anak tersebut. Pelayanan yang diberikan kepada anak cacat dan distabilitas bertujuan untuk memenuhi kesejahteraan anak tanpa membedaan etnic, suku, ras, agama, status sosial, jenis kelamin, dan lain-lain, mengingat bahwa setiap anak memiliki hak-hak yang sama.

2. Undang-Undang Nomor 23 Tahun 2002 atas perubahan Undang-Undang Nomor 35 Tahun 2014 tentang Perlindungan Anak.

Hak-Hak anak telah dituangkan dalam Undang-Undang Perlindungan Anak Pasal 4 sampai dengan Pasal 18 yang menjelaskan hak-hak dasar bagi anak dan dimulai dari pengertian Hak hidup yang merupakan hak-hak dasar yang diberikan langsung oleh Tuhan Yang Maha Esa yang telah melekat dan dimiliki oleh manusia sejak manusia itu lahir guna menjalani hidup, tumbuh dan berkembang layaknya sebagai manusia dan mereka (anak) juga memiliki hak untuk bebas dari penindasan, kekuasaan, pemaksaan. Selain hak hidup, hak dasar lain yang wajib di terima oleh setiap anak adalah untuk mendapat nama sebagai identitas diri dan status kewarganegaraan. Dengan kata lain, anak berhak untuk mendapat hak sipilya, seperti akta-akta yang dikeluarkan oleh catatan sipil.

Hak lainnya yang harus di terima anak adalah hak beribadah menurut agamanya, berpikir, dan berekspresi sesuai tingkat kecerdasan dan usianya, dalam 
bimbingan orang tua. Hak ini dimaksudkan untuk memberikan kebebasan kepada anak dalam mengembangkan kreativitas dan intelektualnya sesuai dengan tingkat usia anak, namun tetap harus berbeda dalam bimbingan orang tua. Selain itu, anak juga harus mendapat hak untuk mengetahui orang tuanya, dibesarkan, dan diasuh oleh orang tuanya sendiri, maka dari itu, orang tua harus menjamin tumbuh kembang anak. Anak dalam keadaan terlantar pun berhak untuk diasuh atau diangkat sebagai anak asuh atau anak angkat oleh orang lain sesuai dengan peraturan perundang-undangan yang berlaku.

Terkait hak yang menyangkut tentang pemberian kasih sayang dari orang tua di atas, anak juga berhak memperoleh pealayanan kesehatan dan jasmani sosial sesuai dengan kebutuhan fisik, mental, spiritual, dan sosial. Terhadap hak ini, pemerintah juga wajib menyediaan fasilitas dan menyelenggarakan upaya kesehatan yang komprehensif bagi anak, agar setiap anak memperoleh derajat kesehatan yang optimal sejak dalam kadungan.

Hak selanjutnya yang berhak diperoleh anak adalah hak memperoleh Pendidikan dan pengajaran dalam rangka pengembangan pribadinya dan tingkat kecerdasannya sesuai dengan minat dan bakat. Anak berhak mendapat perlindungan di satuan Pendidikan dari kejahatan seksual dan kekerasan yang dilakukan oleh pendidik, tenaga kependidikan, sesama peserta didik, dan/atau pihak lain. Pendidikan dan pengajaran dalam rangka pengembangan pribadi dan tingkat kecerdasan, sesuai dengan minat dan bakatnya. Pemerintah pun wajib menyelenggarakan Pendidikan dasar minimal Sembilan tahun untuk semua anak Indonesia.

Pendidikan tidak hanya dalam bentuk formal atau di sekolah saja, tetapi Pendidikan yang di terima anak juga dalam bentuk anak berhak untuk menyatakan dan didengarkan pendapatnya, menerima, mencari, dan memberikan informasi sesuai dengan tingkat kecerdasan dan usianya demi pengembangan dirinya sesuai dengan nilai-nilai kesusilaan dan kepatutan. Artinya, proses pembelajaran yang harus dipenuhi dengan menerapkan pembelajaran yang berpusat kepada anak dengan pelaksanaan pembelajaran yang dapat membantu pengembangan diri dari sang anak dan juga memperluas kesempatan kepada anak dalam mengungkapkan 
pendapatnya, mencari informasi sesuai dengan nilai-nilai kepatutan sesuai dengan usia dan perkembangannya. Dalam mengembangkan dirinya, anak juga berhak untuk beristirahat dan memanfaatkan waktu luang, bergaul dengan anak yang sebaya, bermain, berekreasi, dan berkreasi sesuai dengan minat, bakat, dan tingkat kecerdasannya demi pengembangan diri. Hal seperti ini dapat ditanamkan sejak anak berusia dini dan salah satu cara mengembangkan diri sang anak adalah dengan memberinya waktu untuk bermain.

Bagi anak penyandang disabilitas, mereka berhak untuk memperoleh rehabilitasi, bantuan sosial, dan pemeliharaan taraf kesejahteraan sosial guna terjamin kehidupannya sesuai dengan martabat kemanusiaan, guna meningkatkan percaya diri dan kemampuan berpartisipasi dalam kehidupan.

Dalam hal memberikan perlindungan, setiap anak selama dalam pengasuhan orang tua, wali, atau pihak lain mana pun yang bertanggung jawab atas pengasuhan, berhak mendapat perlindungan dari perlakuan diskriminasi eksploitasi, baik ekonomi maupun seksual penelantaran kekejaman, kekerasan, dan penganiayaan ketidakadilan, dan perlakuan salah lainnya. Setiap anak berhak untuk mendapatkan asuhan dan perlindungan secara langsung dari orangtua kandungnya kecuali dalam beberapa faktor ada yang memungkinkan seeorang anak dapat diasuh dan diberikan perlindungan yang layak oleh seorang wali. Terhindar dari rasa ditelantarkan dimana suatu tindakan atau perbuatan yang secara sengaja maupun tidak sengaja dirasakan dan di dapatkan oleh anak tersebut yang nantinya akan membuat sang anak merasa kehilangan haknya, serta memperoleh perlindungan dari setiap hal yang berkaitan dengan unsur kekerasan yang dapat mempengaruhi mental atau psikis dari anak tersebut. Di lindungi dari Kejahatan, kekerasan, penganiayaan dan ketidakadilan hal ini dapat terjadi dalam bentuk apapun yang akan membuat anak tersebut akan merasa terganggu kenyamananya dan merasa tidak dilindungi serta merasa adanya keberpihakan antara anak yang satu dengan yang lain hal seperti ini dapat sewaktu-waktu terjadi karena mereka merasa tidak dapat keadilan dari orang sekitar. Perlindungan dari perlakuan salah lainnya, yang dimaksud perlakuan salah adalah suatu tindakan senonoh atau pelecehan yang dapat terjadi terhadap anak hal ini benar-benar 
memerlukan pengawasan dari orang sekitar karena dapat mengganggu mental hingga kejiwaan dari anak tersebut. Seorang anak seharusnya memperoleh perlindungan dari hal-hal negatif yang dapat mempengaruhi mentalnya, salah satunya penganiayaan dan penyiksaan. Yang secara psikologis dapat menjadi pemicu adanya faktor-faktor sekitar yang dapat menimbulkan trauma dari anak tersebut

Bagi setiap anak yang dirampas kebebasannya, anak berhak mendapatkan perlindungan dan bantuan hukum yang layak dan pantas agar tidak menimbulkan efek negatif bagi perkembangan dan pertumbuhan mental anak tersebut. Apabila anak menjadi korban atau pelaku tindak pidana, anak berhak mendapatkan bantuan hukum salah satunya seperti memiliki hak untuk di bela di depan pengadilan pengadilan.dan bantuan hukum lainnya.

Selanjutnya, Salah satu tugas dan kewajiban negara dalam pemenuhan hakhak anak terlantar diberikan kepada Kementerian sosial. Kementeriaan Sosial dalam penanganan anak terlantar memiliki kewenangan dan tugas sebagai berikut;

1. Pembuatan regulasi/peraturan berupa NSPK

2. Membantu Anak Terlantar dengan memberikan bantuan Sosial

3. Pembuatan Sistem Data

Langkah-langkah yang telah ditempuh oleh Kementerian Sosial dalam pemenuhan hak anak terlantar adalah dengan membuat Norma, Standar, Prosedur dan Kriteria (NSPK) atau pembuatan regulasi dalam bentuk SPM (Standar Pelayanan Minimum) yang di gunakan sebagai acuan/standar Pemerintah Daerah dalam melaksanakan pelayanan terhadap anak terlantar di wilayahnya, memberikan dukungan dalam bentuk bantuan sosial bagi anak terlantar dalam bentuk Tabungan Sosial Anak Terlantar (TASA) yang diberikan kepada anakanak terlantar di seluruh Indonesia guna pemenuhan hak-hak dasar dan hak sipil. Katagori anak yang mendapatkan bantuan sosial TASA adalah anak terlantar yang juga merupakan salah satu target dalam Progra Kesejahteraan Sosial Anak (PKSA). Bantuan Sosial TASA yang diberikan berupa uang sebesar Rp. 1.000.000 (satu juta rupiah) per tahun yang akan diberikan kepada masing-masing anak terlantar yang tercatat di dalam PKSA oleh Kementerian Sosial. Sumber 
dana yang dialokasikan Rp 1 juta per tahun tersebut berasal dari anggaran Kementerian Sosial. Serta melakukan Pembuatan Sistem Data yang mengacu pada Basis Data Terpadu (BDT) yang dapat memudahkan pemerintah untuk mengakses atau mendata seluruh anak terlantar guna mendapatkan angka yang valid terkait anak terlantar di Indonesia yang nanti akan membantu pemerintah dalam memberikan bantuan guna pemenuhan hak bagi anak terlantar berupa PKH (Program Keluarga Harapan), KIP (Kartu Indonesia Pintar), KIS (Kartu Indonesia Sehat).

Pemanfaatan Bantuan Sosial Tabungan Sosial Anak (TASA) sebesar Rp. 1.000.000,00 / Tahun, adalah sebagai berikut;

1. Untuk pemenuhan kebutuhan dasar seperti;
a. Sandang
b. Papan
c. Pangan

2. Untuk pemenuhan hak sipil berupa;

Hak Identias: Akta Kelahiran, Kartu Keluarga (KK), Nomor Induk Kewarganegaraan (NIK)

3. Aksesibilitas Pendidikan, seperti ;

Beli tas, baju seragam, transport ke sekolah.

4. Aksesibilitas Pelayanan Kesehatan, seperti;

Uang transport ke fasilitas pelayanan kesehatan setempat.

5. Temu Penguatan Anak dan Keluarga (TEPAK)

Dari dana Rp. 1.000.000,00 (satu juta rupiah) yang diberikan melalui TASA akan dialokasikan untuk Tepak sebesar Rp. 300.000,00 (tiga ratus ribu rupiah) guna temu penguatan anak kepada keluarga, salah satu bentuknya sebagai dana untuk mempertemukan anak dengan keluarganya (transport dan konsumsi.)

2. Implementasi pelaksanaan tugas dan kewajiban negara dalam memenuhi hak anak terlantar sesuai dengan Pasal 34 Ayat 1 UndangUndang Dasar Negara Repubik Indonesia Tahun 1945 
Dengan berdasar pada pasal 34 ayat 1 UUD NRI 1945 yang menyatakan fakir miskin dan anak terlantar dipelihara oleh negara, maka penulis berpendapat bahwa belum ada batasan mengenai peran yang harus dilakukan pemerintah dalam pemeliharaan anak terlantar dalam bentuk hukum positif. Sedangkan, jika dilihat hakikat dari isi Pasal 34 UUD itu, dapat dikatakan bahwa uu telahd telah mengamanatkan bahwa dimuka bumi pertiwi nusantara ini tidak boleh ada seorangpun anak yang penghidupannya tidak layak atau berada di garis kemiskinan. Kalaupun ada seorang anak terlantar, maka hal tersebut merupakan pemerintah sebagai representasi dari negara untuk memeliharanya (dalam jangka pendek) serta berusaha untuk membuatnya kembali menjadi sejahtera. Hal ini didukung juga dengan Pasal 20-24 UU perlindungan anak yang menjelaskan mengenai peran serta tanggung jawab negara dalam pemenuhan hak dan perlindungan anak guna menjamin hidupnya dan memberikan kesahteraan baginya.

Selanjutnya, pelaksanaan kewajiban negara dalam memenuhi hak anak terlantar di emban dan di implementasikan oleh Kementrian Sosial Republik Indonesia dan juga Dinas Sosial dalam Pemerintahan Daerah. Kementrian sosial sendiri, seperti apa yang telah penulis jelaskan sebelumnya, bahwa tindakan yang telah di lakukan dalam rangka pemenuhan hak anak terlantar adalah dengan membuat Norma, Standar, Prosedur dan Kriteria (NSPK) atau pembuatan regulasi dalam bentuk SPM (Standar Pelayanan Minimum) yang di gunakan sebagai acuan/standar Pemerintah Daerah dalam melaksanakan pelayanan terhadap anak terlantar di wilayahnya, memberikan dukungan dalam bentuk bantuan sosial bagi anak terlantar dalam bentuk Tabungan Sosial Anak Terlantar (TASA) yang diberikan kepada anak-anak terlantar per tahunnya di seluruh Indonesia guna pemenuhan hak-hak dasar dan hak sipil. Katagori anak yang mendapatkan bantuan sosial TASA adalah anak terlantar yang juga merupakan salah satu target dalam Progra Kesejahteraan Sosial Anak (PKSA). Bantuan Sosial TASA yang diberikan berupa uang sebesar Rp. 1.000 .000 (satu juta rupiah) per tahun yang akan diberikan kepada masing-masing anak terlantar yang tercatat di dalam PKSA oleh Kementerian Sosial. Sumber dana yang dialokasikan Rp 1 juta per tahun 
tersebut berasal dari anggaran Kementerian Sosial. Serta melakukan Pembuatan Sistem Data yang mengacu pada Basis Data Terpadu (BDT) yang dapat memudahkan pemerintah untuk mengakses atau mendata seluruh anak terlantar guna mendapatkan angka yang valid terkait anak terlantar di Indonesia yang nanti akan membantu pemerintah dalam memberikan bantuan guna pemenuhan hak bagi anak terlantar berupa PKH (Program Keluarga Harapan), KIP (Kartu Indonesia Pintar), KIS (Kartu Indonesia Sehat).

Pemanfaatan Bantuan Sosial Tabungan Sosial Anak (TASA) sebesar Rp. 1.000.000,00 / Tahun, adalah Untuk pemenuhan kebutuhan dasar; Untuk pemenuhan hak sipil berupa Hak Identias: Akta Kelahiran, Kartu Keluarga (KK), Nomor Induk Kewarganegaraan (NIK); Aksesibilitas Pendidikan; Aksesibilitas Pelayanan Kesehatan; Temu Penguatan Anak dan Keluarga (TEPAK), Dari dana Rp. 1.000.000,00 (satu juta rupiah) yang diberikan melalui TASA akan dialokasikan untuk Tepak sebesar Rp. 300.000,00 (tiga ratus ribu rupiah) guna temu penguatan anak kepada keluarga, salah satu bentuknya sebagai dana untuk mempertemukan anak dengan keluarganya (transport dan konsumsi.)

Selain itu, pada tingkat daerah, yaitu melalui Dinas Sosial, negara telah memberikan naungan kepada anak-anak terlantar yaitu dengan melakukan penjaringan anak-anak terlantar di daerah kewenangan dinas sosial masingmasing yang kemudian akan dimasukan ke dalam panti sosial dan akan diurus serta di lindungi sehingga hak-hak dari anak yang telah diamanatkan dalam undang-undang akan terpenuhi. Namun, Menurut penulis upaya yang dilakukan oleh pemerintah dalam memberikan perlindungan dan pemenuhan hak anak terlantar belum sesuai seperti yang telah diamanatkan di dalam Pasal 34 Ayat 1 Undang-Undang Dasar Negara Republik Indonesia 1945 yang berbunyi "fakir miskin dan anak terlantar dipelihara oleh negara." Selain itu hal tersebut di dukung oleh Pasal 3 Undang-Undang Perlindungan Anak Nomor 35 Tahun 2014 atas perubahan Undang-Undang Nomor 23 tahun 2002 menyatakan bahwa "Perlindungan anak bertujuan untuk menjamin terpenuhinya hak-hak anak agar dapat hidup, tumbuh, berkembang, dan berpartisipasi secara optimal sesuai dengan harkat dan martabat kemanusiaan, serta mendapatkan perlindungan dari 
kekerasan dan diskriminasi, demi terwujudnya anak Indonesia yang berkualitas, berakhlak mulia, dan sejahtera.” Dan juga Pasal 22 Undang-Undang Perlindungan Anak Nomor 35 Tahun 2014 atas perubahan Undang-Undang Nomor 23 tahun 2002 menjelaskan bahwa "Negara, Pemerintah dan Pemerintah Daerah berkewajiban dan bertanggung jawab memberikan dukungan sarana, prasarana, dan ketersediaan sumber daya manusia dalam penyelenggaraan perlindungan anak."

Dalam kenyataannya, anak-anak terlantar di Indonesia masih banyak yang belum tertanggulangi oleh pemerintah. Hal ini dapat kita lihat secara langsung di berbagai daerah di Indonesia. Salah satu faktor penyebab masih tingginya tingkat anak terlantar di Indonesia yang belum tertanggulangi oleh pemerintah adalah karena pemerintah belum memberikan fasilitas sarana dan prasarana yang memadai secara maksimal dan tepat sasaran kepada anak-anak terlantar sebagai upaya pemenuhan hak-hak juga perlindungan untuk anak-anak terlantar itu sendiri.

Program-program yang pemerintah buat guna pemenuhan hak anak terlantar pun belum seluruhnya tepat sasaran dan dapat menanggulangi permasalahan anak terlantar secara efektif. Hal ini disebabkan oleh beberapa faktor, yaitu:

pertama, anggaran yang disediakan oleh pemerintah baik di tingkat pusat maupun daerah belum mencukupi untuk memenuhi kebutuhan-kebutuhan anak terlantar dan juga anggaran yang dialokasikan pun tidak terdistribusikan secara baik dan efektif guna memenuhi kebetuhan-kebutuhan anak terlantar tersebut. Padahal hal yang krusial dalam penanggulangan anak terlantar di Indonesia adalah dana yang berasal dari anggaran pemerintah karena dana tersebut merupakan sumber utama untuk memenuhi kebutuhan dasar seperti sandang papan pangan, untuk membiayai pendidikan anak terlantar juga fasilitas penunjangan, kesehatan anak terlantar juga fasilitas penunjangnya dan yang terpenting adalah untuk mensejahterakan anak terlantar di Indonesia agar mereka merasakan apa yang anak pada umumnya rasakan karena anak terlantar memiliki hak yang sama seperti anak pada umumnya, bahkan 
Kedua, pendataan anak terlantar di Indonesia juga menjadi faktor yang tidak kalah penting dalam mewujudkan berjalannya program-program yang telah di canangkan oleh pemerintah dalam hal penanganan anak terlantar di Indonesia. Pendataan anak terlantar ini sangat penting karena dengan adanya pendataan yang baik maka anak-anak terlantar di Indonesia akan terdeteksi secara menyeluruh, tidak setengah-setengah. Sedangkan, pendataan terhadap anak terlantar di Indonesia sendiri pun belum maksimal karena pemerintah di yakini belum mempunyai metode yang tepat dalam hal pendataan anak terlantar di Indonesia. Hal ini menyebabkan kinerja pemerintah baik di tingkat pusat maupun daerah tidak berjalan secara baik, karena semua program pemerintah bergantung pada data anak terlantar yang didapatkan, apabila data anak terlantar yang didapatkan oleh pemerintah tidak mencangkup jumlah keseluruhan anak terlantar, maka program yang dijalankan oleh pemerintah pun dapat dikatakan tidak menjangkau kepada seluruh anak terlantar di Indonesia. Lebih lanjut lagi, seperti yang telah kita ketahui bahwa program utama dari pemerintah daerah dalam penanggulangan anak terlantar adalah pembinaan dalam panti sosial, atau penampungan dalam panti sosial, hal ini jelas sangat bergantung pada pendataan anak terlantar, karena penjaringan yang dilakukan oleh pemerintah ini akan berdasar pada pendataan anak terlantar, selain itu program pemerintah pusat yang memberikan bantuan dana langsung kepada anak terlantar di Indonesia, hal ini sangat memerlukan data yang akurat karena perancangan anggaran APBN yang harus direncanakan jauh-jauh hari. Maka dari itu, penulis sangat menekankan bahwa program-program yang pemerintah jalankan belum berjalan dengan efektif dikarenakan factor pendataan anak terlantar yang belum baik.

Ketiga, factor regulasi yang ada dalam hal penanggulangan anak terlantar di Indonesia. banyak kendala terkait regulasi di Indonesia, seperti adanya ketidakharmonisan dalam peraturan perundang-undangan yang menyebabkan implementasi pada penanganan anak terlantar menjadi terhambat. Sebagai contoh, pembatasan wewenang Kementrian Sosial dan Pemerintah Daerah 
dalam penanganan anak terlantar. Di satu sisi, dengan adanya UndangUndang Pemerintahan Daerah, Kementrian Sosial tidak lagi secara langsung menangani anak terlantar di Indonesia, namun di sisi lain, Pemerintah Daerah juga dibatasi kewenangannya dalam hal pemberian bantuan langsung tunai kepada anak terlantar, regulasi di Indonesia telah menentukan bahwa Pemerintah Daerah tidak diberikan wewenang untuk memberikan bantuan langsung secara tunai kepada anak terlantar, melainkan bantuan tersebut harus dalam bentuk barang dan jasa. Hal ini menurut penulis membuat penanganan anak terlantar menjadi tidak efektif, terlalu banyak-nya pembatasan pada pemerintah untuk melakukan tindakan-tindakan dalam hal penanganan anak terlantar membuat ruang gerak pemerintah sendiri menjadi sempit dan yang terkena dampaknya adalah anak terlantar itu sendiri. Penulis berpendapat, akan lebih baik apabila memang ingin mendelegasikan kewenangan penanganan anak terlantar kepada pemerintah daerah, maka berikan kewenangan secara penuh dan pemerintah pusat hanya mengemban tugas untuk mengawasi berjalannya penanganan anak terlantas saja.

Keempat, tidak adanya masyarakat yang dilibatkan dalam penanganan anak terlantar. Anak terlantar hidup dan berkembang di dalam masyarakat Indonesia, yang mana seharusnya masyarakat adalah menjadi organ terdekat dari anak terlantar itu sendiri. Yang menjadi permasalahan disini menurut penulis adalah, pemerintah tidak mengedukasi dan melibatkan masyarakat untuk membantu menangani anak terlantar di Indonesia. Seharusnya, pemerintah melakukan penyuluhan dan sosialisasi terkait dengan anak terlantar, seperti pengenalan anak terlantar, lingkup anak yang dikatakan anak terlantar, cara menangani anak terlantar, dan lain sebagainya. Selanjutnya, pemerintah juga seharusnya memberikan fasilitas untuk masyarakat agar dapat melaporkan apabila dilingkungannya terdapat anak terlantar, sehingga pemerintah pun dapat menangani anak terlantar tersebut. Hal ini juga akan membantu pendataan anak terlantar menjadi akurat dan lebih baik lagi, fasilitas ini bisa dalam bentuk posko pengaduan, atau menggunakan teknologi seperti aplikasi yang kemudian akan di proses oleh pemerintah itu sendiri. 
Jadi, masyarakat akan dengan mudah melaporkan apabila terdeteksi adanya anak terlantar di lingkungan sekitarnya.

Jika di lihat dari sisi keberadaan Pemerintah sebagai salah satu organ penyelenggara negara mempunyai tanggung jawab terhadap pemeliharaan dan pembinaan anak-anak terlantar karena hal tersebut telah di jelaskan di dalam undang-undang perlindungan anak. Memiliki peran sebagai pengatur urusan masyarakat yang berfungsi sebagai pelindung, maka porsi tanggungjawab pemerintah tentu besar dan jauh lebih strategis dalam penanganan anak terlantar. Dalam rangka menjalankan tugas pun harus sesuai dengan tujuan negara, pemerintah sebagai salah satu penyelenggara harus diberikan kewenangan yang tepat dan jelas maksud dan tujuannya. Terlebih, persoalan anak terlantar bukan hanya menyangkut persoalan sosial semata, melainkan terkait dengan persoalan lainnya secara sistemik, salah satunya seperti persoalan ekonomi (kemiskinan beserta penanganannya). Untuk itu pemerintah harus bertindak secara cermat dan sistemik serta mempunyai respon yang sangat tinggi dalam segala hal yang berkaitan dengan pemeliharaan dan perlindungan anak khususnya anak terlantar karena anak terlantar rentan terhadap perlakuan diskriminasi. Dalam memberikan perlindungan terhadap anak terlantar, diperlukan adanya perlindungan anak dalam rangka mengusahakan kesejahteraan anak dan perlakuan yang adil dalam rangka mengusahakan kesejahteraan anak dan perlakuan yang adil terhadap mereka. Hal ini penting demi kelangsungan kegiatan perlindungan anak dan mencegah penyelewengan yang membawa akibat negatif yang tidak diharapkan dalam upaya perlindungan anak.

Maka, penulis simpulkan bahwa implementasi pada penanganan yang telah di lakukan pemerintah, baik dari penyediaan fasilitas sarana pra-sarana juga dari program-program baik yang telah maupun yang akan dicanangkan kedepannya, seperti apa yang telah disebutkan penulis diatas, belum lah efektif dan berjalan dengan baik, hal tersebut diakibatkan oleh beberapa hambatan-hambatan yang sering terjadi seperti seperti misalnya pemenuhan hak anak yang bersifat nonyuridis yang meliputi pelaksanaan terhadap hukum itu sendiri seperti kemampuan aparat penegak hukum, terbatasnya anggaran dan sarana pra-sarana penunjangnya, 
peran dan tanggngjawab orangtua terhadap anak masih dalam skala yang rendah, regulasi undang-undang yang mengatakan bahwa pihak Kementerian Sosial tidak dapat menangani anak terlantar secara langsung dikarenakan terdapat UndangUndang yaitu Undang-Undang Nomor 23 tahun 2014 tentang pelaksanaan Otonomi Daerah yang membatasi lingkup kerja Kementerian Sosial dalam melaksanakan kewajiban dalam perlindungan dan pemenuhan hak anak terlantar sesuai yang tercantum dalam Undang-undang Perlindungan Anak khususnya yang diatur di dalam Pasal 20 , 21, 22, 23, dan 24. Sebagai perwakilan dari Pemerintah Pusat seharusnya mendelegasikan hal-hal mengenai pelayanan atau penanganan langsung kepada anak terlantar di Indonesia.I

\section{Penutup}

\section{A. Kesimpulan}

Terbatasnya alokasi anggaran dalam Anggaran Pendapatan dan Belanja Negara (APBN) yang diperuntukan bagi pelayanan anak terlantar sehingga pemerintah belum bisa maksimal dalam menjalankan amanat yang tertuang dalam Pasal 34 Ayat 1 Undang-Undang Negara Republik Indonesia Tahun 1945. Mesikpun berbagai fasilitas Pendidikan dan kesehtan sudah dibangun oleh pemerintah atau negara namun masih banyak anak-anak yang belum dapat menjangkau atau mengaksesnya. Hal tersebut karena tingginya biaya untuk menjangkau fasilitas-fasilitas yang ada. Disisi lain, masyarakat masih kurang terinformasikan mengenai penanganan anak terlantar.

Adanya beberapa peraturan ataupun regulasi terkait penanganan anak yang tidak saling mendukung sehingga menjadi salah satu faktor penghambat dalam program-program yang diberikan oleh pemerintah. Hal ini mengakibatkan pelayanan yang diberikan oleh pemerintah berjalan kurang efektif dan kurang optimal bagi masyarakat khususnya dalam pemenuhan kebutuhan kesejahteraan anak sehingga dapat menambah populasi anak-anak terlantar.

\section{B. Saran}


Berdasarkan hasil penelitian yang dilakukan oleh penulis terkait tanggung jawab negara terhadap perlindungan anak terlantar di Indonesia, maka penulis memberikan saran sebagai berikut;

1. Perlunya upaya perlindungan dalam bentuk penanganan anak yang menjadi skala prioritas sehingga diperlukan untuk peningkatan alokasi anggaran di dalam APBN yang diperuntukn bagi pelayanan anak-anak terlantar dalam pemenuhan hak-hak dasar anak, mengingat anak adalah generasi penerus bangsa.

2. Perlunya pemerintah dalam menambahkan dan mendekatkan layananlayanan fasilitas dalam bidang kesehatan dan Pendidikan sehingga mudah dijangkau dan dinikmati oleh masyarakat khususnya anak-anak terlantar.

3. Diberikannya sosialisasi lebih yang mendalam sejak dini kepada masyarakat sehingga dapat menumbuhkan rasa empati mengenai penanganan anak-anak terlantar.

Dalam rangka untuk memaksimalkan pelayanan terhadap antar oleh negara diperlukan atau dibutuhkan sinergitas kewenangan-kewenangan yang terdapat dalam Undang-undang untuk kepentingan terbaik bagi anak dengan memberikan pelayanan yang lebih maksimal dan tersebar merata dalam bentuk upaya perlindungan anak terutama dalam pemenuhan hak-hak dasar anak agar lebih terjamin kesejahteraannya.

\section{Daftar Pustaka}

\section{A. Buku}

Abintoro Prakoso, Hukum Perlindungan Anak, Cetakan Pertama, (Yogyakarta: LaksBang PRESSindo,2016)

R.A. Koesnan, Susunan Pidana dalam Negara Sosialis Indonesia, (Bandung :Sumur, 2005)

Romli Atmasasmita, Problema Kenakalan Anak-Anak/ Remaja (Yuridis Sosio Kriminologis), (Bandung: Armico,1983) 
W.J.S. Poerwadarminta, Kamus Umum Bahasa Indonesia, (Jakarta: Balai Pustaka, 1984)

\section{B. Peraturan Perundang-Undang}

Indonesia, Undang-Undang Dasar Negara Republik Indonesia Tahun 1945

Indonesia, Undang-Undang Nomor 35 Tahun 2014 tentang Perubahan atas Undang-Undang Nomor 23 Tahun 2003 tentang Perlindungan Anak

Indonesia, Undang-Undang Nomor 4 Tahun 1979 tentang Kesejahteraan Anak

\section{Artikel Internet}

Bank Data Komisi Perlindungan Anak Indonesia. Data Kasus Perlindungan Anak Berdasarkan Lokasi Pengaduan dan Pemantauan Media Se-Indonesia Tahun 2011-2016.http://bankdata.kpai.go.id/tabulasi-data/data-kasus-seindonesia/data-kasus-perlindungan-anak-berdasarkan-lokasi-pengaduandan-pemantauan-media-se-indonesia-tahun-2011-2016\#sumbar.

Anonim, http://poskotanews.com/2016/11/27/mensos-deklarasikan-indonesiabebas-anak-jalanan-2017/.

\section{Lain - Lain}

Nurini Aprilianda. Perlindungan Hukum terhadap Tersangka Anak dalam Proses Penyidikan. Tesis Program Studi Ilmu Hukum, Program Pasca Sarjana Universitas Brawijaya: Malang, 2001 